\title{
The Change in the Meaning of the Symbol of States' Power in the Area of Medan Merdeka Jakarta
}

\author{
E. A. Airlangga ${ }^{1}$, Susanto $^{2}$, Warto $^{3}$ \\ \{1egaazariaa@gmail.com, ${ }^{2}$ susantofibuns@staff.uns.ac.id, ${ }^{3}$ warto2013@staff.uns.ac.id\} \\ ${ }^{1,2,3}$ Cultural Studies Program, Postgraduate Faculty, Universitas Sebelas Maret
}

\begin{abstract}
The Jakarta downtown area, which is Medan Merdeka area was historically established by the Dutch colonial government. However, this area now has become a national symbol and the central government of the Indonesian Republic. This research aims to find the relations patterns between the urban planning, the states, and the societies through employing structuration theory proposed by Anthony Giddens. The research result concluded that state as a structure and the society as an agent play a role to shape the meaning and the cities' order. The meaning of Medan Merdeka area of Jakarta is continuing to change, in accordance with the social and political conditions of the Indonesian people.
\end{abstract}

Keywords: Urban Planning, Urban Symbolism, Jakarta

\section{Introduction}

The city is a residential area consisting of various buildings which are a unit of residence from various society stratum. A city is not automatically formed, but it is influenced by geographic, political, and socio-economic factors. These factors form a city layout that is filled with various symbols. According to Nas [1], symbol is something that refers to something else, which contains extrinsic values. The city symbolism is demonstrated through various phenomena, such as urban spatial planning, architecture, sculpture, street or regional names, rituals, festivals, processional ceremonies, etc. and in which all of it can be referred as "symbol bearers". According to Lynch [2], a city is built, designed, and reconstructed according to the owner's wishes, which is the people who inhabit it. The image of a city can be seen from the physical form that exist in the city. The physical form in a city is a symbol of the thought and needs of the city dweller. There are five physical elements that affect the city such as the roads, city boundaries, districts, crowds, and regional markers or landmarks.

A certain regime can influence the form of the city planning with the aim of forming an ideology in society. The meaning of a city planning is not permanent, because if a new regime or ideology emerges, they will try to create a new meaning in the city planning. Grabar [3] explains that the meaning of city planning can change without having to completely overhaul its physical form. Hagen [4] stated that the remained form in a different meaning indicates a change in ideology in the urban society. In addition, the meaning of an urban plan can be conveyed through the names of places in the city. The name of a place in the city is usually associated with the historical events or legends that takes place in that place. Cretan and 
Matthews [5], explains that a name is a symbol or ideology of the community itself. The road naming in Timisoara, Romania is using the name of a martyr hero which is a collective memory agenda of the 1989 Revolution. It is to show that Timisoara was the first anticommunist city in Romania. According to Licari [6], words are not only a tool to designate an event or an object but also a tool to build a world that is desired by its owner.

The meaning in form of the words will later be conveyed in physical form which called as a monument. The monument was built as a reminder (memorial), the symbol of a nation or ideology, and a propaganda tool. Because its physical form, the monument is one of the powerful ways for the authorities to show their legitimacy toward the people. Stańczyk [7] and Nassar [8] explains that a monument serves as a tool for political negotiation, legitimacy of power, and the development of the national identity. The meaning of a monument can be changed according to the ideology of the ruling regime and the people point of views. Stevens and Sumartojo [9], Podnar [10] explain that the form of a memorial is as means of propaganda and its physical form is always change from time to time. The memorial's shape in Seoul, South Korea initially symbolized the prominent figures such as the presidents, kings, and generals. After the 1980s, the new memorial was built to symbolize the civil society figures, such as activists of the independent movement, the underground movement, and the grass roots during the Japanese colonial era.

The same thing is also happened in Jakarta, the capital city of the Republic of Indonesia. This largest city in Indonesia was originally just an ordinary port city which later developed into a trade centre and Dutch colonialism and soon after it became the capital city of the Republic of Indonesia. Jakarta or formerly known as Batavia, was one of the first cities in Indonesia built in a western-style urban layout. The Batavia city was built with style of a city in the Netherlands and was filled with the symbols which symbolized the greatness of the Dutch; one of them was Koningsplein or the King's square. The Koningsplein was originally located in the outside of Batavia city, during its development, this area turned into an elite area and later became the colonial's central government. Furthermore, after the Republic of Indonesia was established, the Koningsplein area was changed and rebuilt into Medan Merdeka area which became the central area of the Republic of Indonesia's government. The colonial symbols were removed and replaced with the symbols that symbolizing Indonesian nationalism. This article tries to look the correlation pattern between urban planning, states, and the society which are appreciated in form of symbols. This article is proposed with three questions. The first, how is the history of urban planning in the Medan Merdeka area? Secondly, how is the relationship between the city planning, the state, and the society in the Medan Merdeka area? Last, how does the state (structures) and the societies (agents) influence the urban planning of the Medan Merdeka area?

\section{Research Method}

This research employs a qualitative method. This method was used because it is suitable for understanding the meaning behind the visible data. The social phenomenon cannot simply have understood based on one's words and actions, because everyone has their own thoughts. The qualitative method was employed for examining the history of the development of people's life, using the data documentation such as written notes, maps, and photographs; government regulations, newspapers and magazines. [11] 
The theory used is the structuration theory from Anthony Giddens. This theory was chosen because it explains how the relationship between the state and the communities from both parties. The main theme of the structuration theory is the relationship between the agents and the structures. Agents and structures have inseparable and interrelated duality relations. The agents refer to the concrete person the "the continuous flow of actions and events". Meanwhile, the structure is the rules and the sources that are formed from and form socials recurrence. The agents-structures duality lies in the process of "social structure is both an outcome and a means of social practices" [12]. Giddens sees the structures as an outcome and also as the medium of social practices. According to Giddens, there are three main structural elements, signification, domination, and legitimation [13]. The signification structure involves symbolic scheme, mentioning, and discourse. The domination structure concerns about the scheme of controlling over people (politics) and goods (economics). The legitimation structure concerns about the normative regulatory scheme which is revealed in the legal system [14]. According to Giddens, the agents can leave a structure because the agents is not always subject to the structure. The agents can look for opportunities or possibilities to get out of the rules and regulations, this situation is often called as dialectic control. The core of structuration theory is not on the agents or the structures but on the social practices; which about how humans live their daily lives both in the relation with their family and friends as well as with the office employees, bureaucrats, and others [15]. According to the structuration theory the society is produced and continuously reproduced every day in space and time.

Another theory used in this article is from the opinion of Benedict R. O'G Anderson which about political communication in Indonesia. There are two types of political communications, they are direct speech and symbolic speech. Direct speech is the most commonly used form of political communication, such as gossips, rumours, discussions, arguments, interrogations, and intrigues. Direct speech has a character of fast and temporary, during its process it is converted into an illustration or symbolic representation. The symbolic speech is an ambiguous form of political communication, the meaning can be shifted, deep, reverse, or dry up over the time. The example of symbolic communications are cartoons, advertisements, films, and monuments [16].

\section{Results And Discussion}

\subsection{Koningsplein, The Symbol of The Colonial City Batavia}

Koningsplein (the King's Square) is a public space area in the Batavia city, which was designed as the centre of the Dutch government and cultural area. Koningsplein can be said as a change symbol of the state order from the east Indies managed by the East Indies Trade Union or Vereenigde Oostindische Compagnie (VOC) into Dutch East Indies managed by the Dutch colonial government.

Batavia city was established after the VOC forces under the command of Jan Pieterszoon Coen take over Jayakarta from the Prince of Jayakarta. The VOC transformed Jayakarta into Batavia, which was design similar with a city in the Netherlands. It is surrounded with canals and fortresses which served as both a defence and water controller.

After the VOC went bankrupt in 1799s, the former VOC territory was held by the Dutch Kingdom. Deandels, Governor General of the Dutch East Indies [17], considered that Batavia was no longer habitable because it is full of epidemics (especially malaria) and it was not suitable for a colonial central government. Deandels chose the outskirt of Batavia to be a 
candidate for the central of the Dutch East Indies Colonial government named Weltevreden [18]. Early before $1800 \mathrm{~s}$, Weltevrede was often used for animals hunting ground especially for hunting bulls and tigers, so it was often called Buffelsveld (Banteng Field). In 1809's, Deandels flatten the field and use it as a military training ground and named as Champ de Mars (Mars Field).

After Deandels and Raffles era, this field was renamed as Koningsplein. In the early of the $19^{\text {th }}$, this region was considered as a "paradise" for the Europeans, because of its cool air, lots of trees, and its vast land. However, in the late $19^{\text {th }}$ Koningsplein is quickly turned into a large multifunctional public space, surrounded by two churches, two leading hotels in the Batavia city, the city theatre (Schouwberg), and the European convention and cultural centre, Harmonie Club, as well as plenty of vocational houses [19]. In the $20^{\text {th }}$ century, the colonial government had planned to convert Koningsplein as a city park but it did not happen. Thus, this area becomes irregularly compartmentalized. On the north side there are several parks, such as Helbachpark, Frombergpark, and Deca Park which consists of cinemas and other buildings. Furthermore, on the south side there are Gambir Market complex, a bazaar that exhibits arts and crafts from all over countries and sports area of Bataviasch Sport Club. While, on the west side was built a large police headquarters and on the east side there is $S . S$. Koningsplein's hotel [19].

\subsection{Medan Merdeka, The Symbol of Jakarta-The Republican City}

In the 1942s, the Japanese imperial army occupied Batavia and changed its name into Jakarta. Jakarta is derived from the word Jacatra, the Portuguese terms for the Jayakarta city. In addition, Koningsplein was renamed into Gambir Field (Lapangan Gambir). On August 17, 1945 s the Indonesian people proclaimed their independence in Jakarta, however Jakarta did not immediately become the nation's capital. During the independence war (1945s-1949s), the nation's capital steadily keeps moving, for example in Yogyakarta and Bukittinggi. After 1950 s, Soekarno intended to make the country's capital as a symbol of Indonesian's unity and the spirit of Indonesian revolution or nationalism. Soekarno used a blend of the traditional architecture with International style architecture, which named by Soekarno as Nation Building style. It is applied in the governmental buildings, and public spaces to shows to the world that Indonesian is a developed country and not left behind by the other countries/ nations [18], [19]. The Indonesian capital concept created by Soekarno was themed Indonesian Socialism. Soekarno's hope was to throw the colonialism symbols from the capital city. Jakarta was designed as the "lighthouse" of a new, independent and powerful state.

Soekarno ordered his trusted architects to redesign Jakarta, as the nation's capital and the symbol of the national identity especially in the Gambir Field area [18]. On 1951s, the Bataviasch Sport Club football field was renovated into IKADA stadium (Djakarta Athletics Associations) which was used for the second National Sports Week (PON). This stadium bears witness to nationals and internationals matches and also symbolize the Indonesian's existence as a "new independent nation" in the sports fields. In addition, all the park names in Gambir Square that symbolize colonialism were renamed. Helbachpark was renamed into Taman Amir Hamzah, Frombergpark changed into Taman Chairil Anwar and Taman W.R. Supratman. While, Gambir Market area was renamed into Taman Ronggowarsito.

Since returning to Jakarta in 1950s, Soekarno had imagined Gambir Field as the Indonesian's "square". This view was influenced by the Javanese royal city layout, in front of the palace (president) there is a square and on the both side there are religious centre. In addition, Soekarno also wanted to make a large monument in the middle of Gambir Square which symbolized the identity of the Indonesian people [18]. On 1961s, President Soekarno 
started the megaproject by displacing many buildings and city parks from the Gambir Field area for the National Monument project. The evictions of parks and colonial buildings became the land for the National Monument symbolizing Soekarno's anti-colonial attitude and also campaigning the revolutionary spirit. He tried to erase the colonial legacy and replace it with something made by the country's children. The National Monument is designed in the form of an obelisk, it is combined with a cup-shaped building so that it is shaped like lingga-yoni. It is symbolizing the identity of the Indonesian people. This project had stopped for a moment because of the event of the September 30, 1965 Movement and the anti-Old Order Movement, but soon the project is continued during the President Soeharto's era. The National Monument was completed in 1968s and the Medan Merdeka park area was completed in 1975s. on 1993s, the government decided that the Medan Merdeka area as the central government area [19].

\subsection{The Relation Between the State, Community, and Jakarta's Medan Merdeka Area}

To find out the relationship between the urban planning, the state, and the society; first it needs to find what roles should be played by urban planning, the state, and the society from the point of view of structuration theory. The state can be said as the "structure" and the society as the "agents" and the urban planning can be said as "the result of the structuresagents' relationship (social practices)". The urban planning is formed not only form the structures (through the projects, regulations, city planning) but also from the agents (as the residents and executors of the socio-economic life). The changes in structures or agents will affect the shape of the city, buildings, and the meaning of the city. This change can be seen in the Batavia city, which changed into Jakarta (especially in the Medan Merdeka area), both in terms of its structures and agents. According to Giddens there are three main structural elements, they are signification, domination, and legitimation [13]. The following table is the three main structural elements of the Medan Merdeka region.

Table 1. Three main structural elements of the Medan Merdeka Region

\begin{tabular}{lll}
\hline \multicolumn{1}{c}{ Structure } & \multicolumn{1}{c}{ Koningsplein Batavia } & \multicolumn{1}{c}{ Medan Merdeka Jakarta } \\
\hline Signification & $\begin{array}{l}\text { The triumph symbol of the Dutch } \\
\text { East Indies }\end{array}$ & $\begin{array}{l}\text { The national symbol of the Republic } \\
\text { of Indonesia }\end{array}$ \\
$\begin{array}{l}\text { Domination } \\
\text { (Politics) }\end{array}$ & $\begin{array}{l}\text { The centre of the Colonial } \\
\text { Military Training Ground }\end{array}$ & $\begin{array}{l}\text { The Republican centre government } \\
\text { Domination } \\
\text { (Economics) }\end{array}$ \\
$\begin{array}{l}\text { The city's park } \\
\text { The Market } \\
\text { Sports complex } \\
\text { The use must be authorized by the } \\
\text { colonial government }\end{array}$ & $\begin{array}{l}\text { The city's park } \\
\text { Tourist destination }\end{array}$ \\
& $\begin{array}{l}\text { Neutral zone area } \\
\text { The use must be authorized by the } \\
\text { government of Jakarta city }\end{array}$ \\
\hline
\end{tabular}

From the agents' side there are two groups of agents, they are the authorities and the peoples. The agents can leave the structures; they are not always subject to the structure. The agents can look for an opportunities or possibilities to get out from the existing rules and regulations and it is called as dialectic of control [15]. In the colonial's structure era, the Koningsplein area is functioned as the colonial central government, a military training ground, and the public spaces such as the parks, markets, and the sport complexes. At the time when the colonial was collapsed, the agents (non-European societies) had the opportunity to carry out their dialectic of control and finally create a new structure which is soon replaced Koningsplein into a region that symbolizing the existence of the Indonesian nation called Medan Merdeka. 
The structures and the agents are a unit that influences one another or duality. Structures can affect the agents and vice versa, the agents can affect the structures. The relationship between the agents and the structures create a social practice, that is about how the humans live their daily lives both in relation with their family and friends as well as with the office employees, bureaucrats, and the others. The structures-agents' duality lies in the fact that there is a scheme resembles "the rules" which are the principles for the social practices in various places and times. These are the outcome repetition of our actions and at the same time also as the schemata-like scheme that soon become a medium for social practices to take place [14]. This process of social practices affects what happens in this world, one of them is the urban planning as the human settlement area. The following is the relationship chart of the social practices in the urban planning of the Medan Merdeka region.

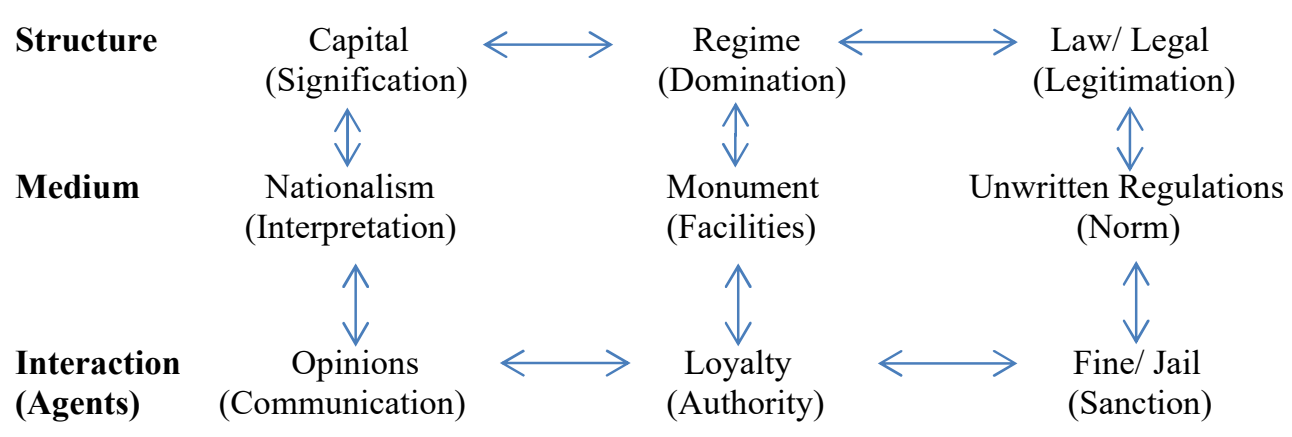

Fig 1. Relationship of Social Practices in Urban Planning in the Medan Merdeka Region

The capital status as "signification" is formed from the repeated "discourse" that the central government is the Batavia or Jakarta. The regime carried out the standard "domination" scheme of the "control" practice through the medium and one of them is the VOC and colonial or republican institutions. The colonial or republic "legitimacy" scheme becomes a standard through the repeated application of "sanction", for example Koningsplein must be used for activities related to colonial, while Medan Merdeka area becomes neutral zones, the violations causing fines or imprisonment. According to Giddens, power is transformative capacity, which is the ability to intervene in certain events and make changes. Power is revealed if it used a structure [20]. In the previous picture, the structures-agents' duality is always involving "medium". The signification-communication duality is through an "interpretation". The capital is the centre of the country, thus the capital becomes the symbol of nationalism. The domination-power duality is through a "facility". The regime shows their domination through the outstanding project, thereby generating loyalty then creating a solid regime. The legitimacy-sanction duality is through the "norms" [21]. The use of Medan Merdeka should be authorized by the government, because is the national "sacred" area, thus any violations will be punished. 


\section{Conclusion}

In the case of Medan Merdeka in Jakarta, the structures and the agents create a social practice in form of the urban planning. The city's developments and arrangements is adjusted to the state structures and its agents. When the structures and the agents create a social practice of "colonial state", all of the buildings are used for colonial glory. If there is a dialectic control, the structures and agents are changed themselves, produce and reproduce into a new social practice, known as "republican state". All the old buildings were removed (demolished) or change its meaning, thus it fit with "republican state" and at least strengthen this new system. The duality between the structures and the agents occur in a social practice that are repetitive and patterned across time and space. The community will always produce and reproduce through the structures-agents' duality and social practices.

\section{References}

[1] P. J. M. Nas, City Full of Symbols. Leiden: Leiden University Press, 2011.

[2] K. Lynch, The Image of The City. Cambridge: The M.I.T. Press, 1990.

[3] H. S. Grabar, "Reclaiming the city: changing urban meaning in Algiers after 1962," Cult. Geogr., vol. 21, no. 3, pp. 389-409, 2014.

[4] J. Hagen, "Architecture , Symbolism, and Function: the Nazi Party' s ' Forum of the Movement '," Environ. Plan. D Soc. Sp., vol. 28, pp. 397-425, 2010.

[5] R. Cretan and P. W. Matthews, "Popular responses to city-text changes: street naming and the politics of practicality in a post-socialist martyr city," Area, vol. 48, no. 1, pp. 92-102, 2016.

[6] G. Licari, "World Futures: The Journal of New Paradigm Research Anthropology of Urban Space : Identities and Places in the Postmodern City," World Futures, vol. 67, pp. 47-57, 2011.

[7] E. Stańczyk, "Remaking National Identity: Two Contested Monuments in Post-Communist Poland Remaking National Identity: Two Contested Monuments in Post-Communist Poland," Cent. Eur., vol. 11, no. 2, pp. 127-142, 2013.

[8] A. Nassar, "Staging the State : Commemoration, Urban Space and the National Symbolic Order in 1970s Cairo Staging the State: Commemoration, Urban Space and the National Symbolic Order in 1970s Cairo," Middle East Crit., vol. 28, no. 3, pp. 1-19, 2019.

[9] Q. Stevens and S. Sumartojo, "Shaping Seoul's memories: the co-evolution of memorials , national identity, democracy and urban space in South Korea's capital city Korea's capital city," J. Urban Des., vol. 24, no. 5, pp. 1-21, 2018.

[10] I. Podnar, "Contemporary Religious Architecture in Zagreb as an Element of Urban Iconography," IKON, vol. 8, pp. 229-244, 2015.

[11] Sugiyono, Memahami Penelitian Kualitatif. Bandung: Alfabeta, 2005.

[12] A. Giddens, The Constitution of Society: Outline of the Theory of Structuration. Cambridge: University of California Press, 1984.

[13] B. H. Priyono, Anthony Giddens: Suatu Pengantar. Jakarta: Kepustakaan Populer Gramedia, 2003.

[14] A. Gidden and B. H. Priyono, "Sebuah Terobosan Teoritis," BASIS, vol. 49, no. 01-02, pp. 1623,2000 .

[15] I. Wibowo, Negara dan Masyarakat: Berkaca dari Pengalaman Rakyat Cina. Jakarta: Gramedia Pustaka Utama, 2000.

[16] B. R. O. Anderson, Language and Power: Exploring Political Cultures in Indonesia. Cornell University Press, 1990.

[17] D. Lombard, Nusa Jawa: Silang Budaya Kajian Sejarah Terpadu Bagian I: Batas-Batas Pembaratan. Jakarta: Gramedia Pustaka Utama, 2005.

[18] C. Silver, Planning the Megacity: Jakarta in the Twentieth Century. London: Routledge, 2007. 
[19] A. Heuken, Medan Merdeka - Jantung Ibukota RI. Jakarta: Yayasan Cipta Loka Caraka, 2008.

[20] A. Giddens and I. Wibowo, "Negara dan Modernitas," BASIS, vol. 49, no. 01-02, pp. 34-43, 2000 .

[21] K. Saddhono, "Language and superdiversity: Indonesians knowledging at home and abroad. By Zane Goebel." Soc. Stu. vol. 12 no.1 pp. 113-118, 2018 